Article

\title{
"Let's Talk about It"-Explicit Discussions as a Way to Reduce the Resistance of Religious Jewish Science Teachers to Learning and Teaching about Evolution: A Case Study
}

\author{
Iris Alkaher ${ }^{1, *(D)}$, Marva Shmueli ${ }^{1}$ and Amos Dreyfus ${ }^{2}$ \\ 1 The Center for Environmental and Sustainability Education, Kibbutzim College of Education, \\ Technology and the Arts, Tel Aviv-Jaffa 6250769, Israel; shmueli15@walla.co.il \\ 2 Faculty of Agriculture, Food and Environment, the Hebrew University of Jerusalem, \\ Jerusalem 9190401, Israel; amos.dreyfus@mail.huji.ac.il \\ * Correspondence: iris.alkaher@smkb.ac.il; Tel.: +972-3-6902-324
}

Received: 19 September 2020; Accepted: 19 October 2020; Published: 23 October 2020 updates

\begin{abstract}
Acknowledging the diverse perceptions about science-religion relationships among learners who come from various religious environments may increase learners' willingness to learn about evolution. This study is based on a zoology course designed for in-service teachers, which aimed to provide basic scientific knowledge about evolution using the Religious cultural competence in Evolution Education framework. The study explores whether learners who were resistant to evolution modify their attitudes and willingness to learn about it, and whether they develop respect toward learners who hold contradicting views. Using qualitative methods, the findings indicate that using the Religious cultural competence in Evolution Education framework increased some formerly "resistant" learners' willingness to learn about evolution and include it in their own teaching, albeit in varying degrees and with various reservations. The learners appreciated the freedom to express their challenges concerning evolution learning or teaching and became more willing to respect opposing perspectives, even though not all the religious learners accepted evolution as an explanation for the development of organisms. This study has international implications for bridging the gap between science and religion, thus reducing resistance to learning and teaching about evolution.
\end{abstract}

Keywords: cultural competence; evolution teaching; religious cultural competence in evolution education; action research; resistance to evolution learning; Jewish

\section{Introduction}

For many years, the scientific community has strongly agreed that evolution is central to unifying the principles of biology, with sufficient supporting evidence [1]. Scientists and science educators widely agree that learning about the evolution theory is fundamental to understanding biological processes and the nature of life and is the only coherent scientific theory. In Dobzhansky's terms "Nothing in biology makes sense except in the light of evolution" [2]. Nevertheless, for a variety of reasons [3-7] many science teachers tend to exclude the topic of evolution from their teaching: Some teachers find it difficult for students to understand evolutionary processes, and others feel that evolution contradicts their personal religious beliefs [8-10]. Furthermore, some teachers prefer to abstain from teaching about evolution because they feel that they lack the tools and skills necessary for teaching such a controversial topic and, in many cases, evolution is simply not included in the school curriculum. Orin, Frankel and Ziv [11] conducted a study in Israel investigating the attitudes of 241 primary school biology teachers toward evolution and found that one third of them chose not to 
teach evolution at all. Most of these teachers invoked religious beliefs-either their own, their students' or the school management's. One quarter of the teachers claimed that their choice not to teach it was due to a lack of necessary scientific knowledge and didactic tools.

This study is based on a zoology course, designed for in-service primary school biology teachers. One of the main objectives of the course was to provide the teachers with the basic scientific knowledge necessary to assess rationally the cultural, social and educational implications of evolution. The course instructor had assumed that, being a scientific theory, the theory of evolution should be taught as such, i.e., without any reference to religious considerations. However, peer-observation by a colleague together with her own experience in teaching evolution revealed that some religious learners strongly rejected the idea of evolution, considering it to be a blasphemous heresy, in total contradiction to the Holy Scriptures. Evolution was therefore an illegitimate and unacceptable explanation for the variety of species in nature, especially in relation to the origins of humankind, and they refused to learn about it. In this study, we describe an attempt to redesign the teaching strategy to make the topic of evolution more palatable to resistant learners. The newly designed course was monitored by means of an action research, the objectives of which were to provide the researchers with continuous information about "what happened", to be used as part of the reflective decision-making aimed at improving the course.

The teaching of evolution in schools as well as in higher education becomes more challenging when students come from diverse cultural and mainly religious backgrounds, as in our study. In such settings, instructors might be confronted with substantial difficulties in their teaching, due to the classroom climate that results from the varying degrees of students' resistance to learning about evolution, and because of students' conflicting conceptions about the importance of teaching this topic. Another substantial challenge that is more likely to occur in biology classrooms in higher education (which is the context of this study), refers to the religious cultural differences between the science instructors, who are mostly secular, and the students, who come from diverse religious cultures. It has been found that there is a notable gap between the relatively high percentage of religious students in biology classes and the relatively low percentage of biologists and biology instructors with a religious identity [8-10]. A common claim raised by secular biology instructors in colleges is that there is no room for religion in biology classrooms, showing a lack of awareness of the uneasiness caused to their religious students by the conflict they perceive between their religious beliefs and the theory of evolution [12]. In addition, these instructors struggle to understand the students' conflict because they do not experience such a conflict themselves. In such situations, the students often challenge the teacher's instructional practices [12,13].

Biology instructors may consider that by explaining the theory to unwilling students using a top-down approach, they have fulfilled their obligations, but, if they believe they must teach every student, even those who are offered knowledge but refuse to learn, then they must be provided with a suitable strategy to do so. In this context, several scholars have suggested the use of cultural competence, to bridge the gaps between people from different cultures, thus making possible effective communication between them [12].

cultural competence was defined by Betancourt et al. [14] as the acknowledgment of "the importance of culture, assessment of cross-cultural relations, vigilance toward the dynamics that result from cultural differences, expansion of cultural knowledge, and adaptation of services to meet culturally unique needs". This strategy was recommended specifically for college biology instructors [15] and, more specifically, when teaching evolution [12]. Focusing on the lens of cultural competence, in this study we adopted the Religious cultural competence in Evolution Education (ReCCEE) framework suggested by Barnes and Brownell [12] as a framework for culturally competent evolution education in the context of a zoology course for in-service science teachers.

Focusing on bridging the cultural gap between non-religious instructors teaching evolution and religious students, Barnes and Brownell [12] suggested adopting the ReCCEE framework to assist the instructors in their evolution teaching. According to this framework, instructors need to 
implement several practices in the classroom: acknowledging, exploring, teaching the nature of science, outlaying the range of viewpoints, providing role models and highlighting potential compatibility. These practices are further described below. In this study, we also used the ReCCEE framework to assist students from different religious cultures in their evolution learning, focusing on bridging their cultural gaps toward acknowledging and accepting different perceptions about evolution.

\section{Literature Review}

Most researchers agree that it is important to acknowledge the existence of diverse perceptions among students about the relationship between science and religion [16,17]. Such an acknowledgment may reinforce students' trust in science educators, increasing their willingness and motivation to learn about scientific topics they view as controversial or cause for conflict $[18,19]$. Moreover, explicit discussions about the tension between science and religion, particularly in the context of evolution, may help students bridge the apparent gap between religious and scientific perceptions, thus reducing their resistance to learning about evolution [7,20-22]. Sikkink [22] emphasized that discussing evolution with students in relation to their religious beliefs can make them realize that accepting evolution does not require them to renounce their faith. Furthermore, classroom discussions may give students the opportunity to confront their own perceptions of conflict between science and religion with those of their peers, thus eventually expanding their own views and making it less difficult for them to accept the scientific explanation of the development of life [23].

Researchers have stressed the need for instructors to develop their own level of cultural competence to enable them to address the cultural dilemmas of their students. In this context, cultural competence "is the ability to successfully teach students who come from different cultures other than your own. It entails mastering certain personal and interpersonal awarenesses and sensitivities, learning specific bodies of cultural knowledge, and mastering a set of skills that, taken together, underlie effective cross-cultural teaching" [24]. Tanner and Allen [15], who addressed specifically the role of cultural competence in college biology teaching, claimed that college biology instructors need to develop their own cultural competences to increase the degree of involvement, access and success of culturally diverse students in their biology courses. They indicated four strategies that these instructors should employ in this context, ranging from the simplest to the most complex: monitoring and changing ordinary language in the classroom, becoming aware of patterns of interaction with students, integrating cultural relevance and diverse role models into curricula, and confronting and revising differing expectations and stereotypes of students [15].

Barnes and Brownell [12] attempted to sum up these views within the framework of their ReCCEE, claiming that it is crucial to assist biology instructors in their efforts to bridge the cultural gap between their own non-religious perception of evolution and the religious culture of their students. Bridging this gap could improve the relationship between biology instructors and religious students, as well as increasing students' trust in scientists and consequently influencing their views about evolution [25]. Barnes and Brownell [12] outlined six evidence-based culturally competent practices that can help reduce students' perceived conflict between evolution and religion, and create a more palatable classroom environment for religious students:

1. Acknowledge that some students may perceive a conflict between their religious beliefs and the theory of evolution. Students may appreciate their science instructor's tolerance toward their religious beliefs that conflict with the theory of evolution. That could help them develop more positive attitudes toward evolution [26]. Instructors can implement this practice by surveying and interviewing their students on their beliefs about religion and evolution, their acceptance of evolution and the conflict they perceive (if at all) between their religious beliefs and evolution. Instructors should also acknowledge the differing views that students have, while keeping the different beliefs confidential.

2. Explore students' personal views on evolution and religion. Instructors should provide students the opportunity to express, discuss and reflect on their own and other students' views on religion and 
evolution. This practice allows students to debate critically about their own and others' views on evolution and may increase the possibility that they will accept evolution in the future [27]. Students' writing in reflective journals during a course was found as an effective strategy to achieve this [28].

3. Teach the nature of science. Previous studies have found that discussing the nature of knowledge, different ways of knowing and the bounded nature of science was effective in bridging the cultural gap between religious and non-religious students in biology classes [3,29,30]. Group discussions in which students discuss and categorize different questions according to their alignment to the scientific method are suggested as an effective strategy to achieve this. Examples of such questions are: "How old is life on Earth?" and "Do humans share a common ancestor with chimpanzees?"

4. Outline the spectrum of viewpoints. Instructors should increase students' awareness to the range of viewpoints on the relationship between evolution and religion, and not only the two dichotomous ones-atheistic evolution versus creationism. By doing this, some of the students can choose positions that allow their religious beliefs to coexist with evolution [31]. Effective strategies for achieving this are instructors' presentations on different positions on the relationship between evolution and religion and official stances of different religious denominations on evolution (e.g., different churches, different Jewish Rabbinical approaches).

5. Provide religious role models who accept evolution. Instructors can reduce perceived conflict between evolution and religion by introducing their students to role models who are both religious and accept evolution. This could also decrease a common misconception that one must be either an atheist who accepts evolution or a religious person who rejects evolution [32]. Reading biographies of scientists who are religious and accept evolution and inviting to the class religious scientists who reconcile religious beliefs and evolution to discuss with the students how they do it, are suggested as effective strategies for providing such role models.

6. Highlight potential compatibility between evolution and religion. Instructors can reduce perceived conflicts between evolution and religion by providing specific examples that demonstrate compatibility between the two and weaken the false dichotomy between them. This practice is highly recommended in previous literature on evolution education [28,33-36].

To maximize the effect of using the ReCCEE framework on students' evolution learning, all six practices were implemented during the course and the action research, as recommended by Barnes and Brownell [12]. This is presented in Table 1 and also described below. 
Table 1. Cycles of action research.

\begin{tabular}{|c|c|c|c|c|}
\hline Teaching Goals & Scientific Principles $^{1}$ & Contents & Activities & ReCCEE Practices \\
\hline \multicolumn{5}{|c|}{ Stage 1-Evolution "without evolution"-Before bringing in the explicit concept of evolution } \\
\hline $\begin{array}{l}\text { Developing a positive attitude toward the course, } \\
\text { and preparing the students for learning about the } \\
\text { principles of evolution. } \\
\text { Creating a comfortable atmosphere of tolerance for } \\
\text { varied opinions. } \\
\text { - Reducing the expected resistance toward the } \\
\text { theory of evolution. } \\
\text { Developing curiosity, connection to nature and } \\
\text { positive attitudes toward animals. }\end{array}$ & $\begin{array}{l}\text { - There is a correlation between the } \\
\text { characteristics of an individual/a species and } \\
\text { the environment in which it lives. } \\
\text { - All living things reproduce when they } \\
\text { reach maturity. } \\
\text { - All offspring are similar to their parents, but } \\
\text { not identical to them. }\end{array}$ & $\begin{array}{l}\text { - Linnaeus' taxonomy of living creatures. } \\
\text { The characteristics of biological species. } \\
\text { Types of reproduction in animals. } \\
\text { The different ways in which animals are } \\
\text { adapted to various environments. }\end{array}$ & $\begin{array}{l}\text { - Introduction to biodiversity through: } \\
\text { Guided lab activity, independent inquiry, } \\
\text { active experience with animals. } \\
\text { - Outdoor inquiry activities with animals } \\
\text { in the nearby environment. } \\
\text { Survey about students' beliefs concerning } \\
\text { evolution and religion. }\end{array}$ & - Acknowledge, explore. \\
\hline \multicolumn{5}{|c|}{ Stage 2-Darwin's journey toward evolution-Introducing the concept of evolution with no explicit reference to humans } \\
\hline $\begin{array}{l}\text { - Identifying students' perceptions toward the } \\
\text { theory of evolution. } \\
\text { Developing their scientific understanding of the } \\
\text { theory of evolution by gradually teaching } \\
\text { its principles. } \\
\text { - Exposing students to Darwin's personal conflict as } \\
\text { a basis for conflicts today. } \\
\text { Introducing the historical period in which the } \\
\text { theory was developed. } \\
\text { Developing a preliminary, explicit discussion of the } \\
\text { science-religion tensions in the context of } \\
\text { evolution, and especially Darwin and his theory. }\end{array}$ & $\begin{array}{l}\text { The earth is } 4.5 \pm 0.5 \text { billion years old; long } \\
\text { enough for gradual geological changes and } \\
\text { the development of living creatures. } \\
\text { The principle of natural selection: (a) Rests } \\
\text { on the existence of diversity within species; } \\
\text { (b) Not all individualal in a species will reach } \\
\text { maturity and procreate; (c) The offspring that } \\
\text { are best fitted to the environment will } \\
\text { survive; (d) Every species develops particular } \\
\text { characteristict that fit a specific niche in the } \\
\text { habitat to prevent competition with } \\
\text { other species. } \\
\text { - Randomness in nature: Mutations are } \\
\text { random and not generated in response to a } \\
\text { particular need. }\end{array}$ & $\begin{array}{l}\text { - } \quad \text { Cosmological evolution. } \\
\text { - } \quad \text { Historical evolution. } \\
\text { - } \\
\text { Biological evolution. } \\
\text { humans). }\end{array}$ & $\begin{array}{l}\text { - Independent research into Darwin's story } \\
\text { and the development of his theory of } \\
\text { natural selection. } \\
\text { - Class discussion of Darwin's conflict in } \\
\text { the context of species formation through } \\
\text { natural selection. } \\
\text { - Class discussion of religion-science } \\
\text { tensions in the context of evolution, } \\
\text { including students' beliefs. }\end{array}$ & $\begin{array}{l}\text { - Provide role models, highlight } \\
\text { potential compatibility. } \\
\text { Outline spectrum of views, } \\
\text { highlight } \\
\text { potential compatibility. } \\
\text { - Outline spectrum of } \\
\text { views, explore. }\end{array}$ \\
\hline \multicolumn{5}{|c|}{ Stage 3-The challenge of evolution—Were we made in God's image? Focusing on human development in light of evolution } \\
\hline $\begin{array}{l}\text { - Developing a scientific understanding of the theory } \\
\text { of evolution. } \\
\text { - Scientific introduction to early hominids: } \\
\text { humanity's ancestors. } \\
\text { Developing a discussion of the origins of humanity } \\
\text { in the context of science--religion tensions, focusing } \\
\text { on the Jewish perspective. }\end{array}$ & $\begin{array}{l}\text { The process of evolution occurred over } \\
\text { billions of years, resulting in such a broad } \\
\text { diversity of species. } \\
\text { All living species, including Homo sapiens, } \\
\text { evolved from a single common ancestor. }\end{array}$ & $\begin{array}{l}\text { - The characteristics of mammals } \\
\text { and primates. } \\
\text { The evolution of various hominids and } \\
\text { Homo sapiens. } \\
\text { Central discoveries in the study of early } \\
\text { humans and their ancestors. }\end{array}$ & $\begin{array}{l}\text { - Class discussion of various approaches in } \\
\text { Judaism to the } \\
\text { science-religion relationship. } \\
\text { - Guest lecture from a religious scientist. } \\
\text { - Learning from skeletons and skulls about } \\
\text { the similarities between different } \\
\text { mammals, including primates. } \\
\text { - Class discussion about social dilemmas } \\
\text { surrounding human evolution. } \\
\text { - Final survey about students' beliefs } \\
\text { concerning evolution and religion. }\end{array}$ & $\begin{array}{l}\text { - Outline spectrum of views, } \\
\text { highlight } \\
\text { potential compatibility. } \\
\text { - Provide role models, highlight } \\
\text { potential compatibility. } \\
\text { - Teach the nature of science. } \\
\text { - Explore, outline spectrum } \\
\text { of views. } \\
\text { - Acknowledge, explore. }\end{array}$ \\
\hline
\end{tabular}

${ }^{1}$ Based on Lerner, 2000, p. 18 [37] 
Before we present the study and its main outcomes, two points must be made clear: First, the resistance to the theory of evolution is not specific to orthodox Jews. According to some surveys, the intelligent design and creationist approaches appear to be quite popular, especially in relation to the origins of humankind, even in Western countries, where there is a legal separation between church and state [8,22,38-40]. However, European surveys [41] found that in 31 out of 32 participating countries, at least $50 \%$ of respondents agreed with the statement: "Human beings, as we know them today, developed from earlier species of animals." In Israel, however, religion appears to be quite present. A survey conducted in June 2005 by Yaar [42] found that $66 \%$ of the Jewish participants described themselves as believers in God and 22\% as non-believers, while $93 \%$ of the Arab participants described themselves as believers in God. The survey found that only 33\% of the Jewish Israelis and $2 \%$ of the Arab Israelis agreed that "humans were created through a process of evolution," while $53 \%$ of the Jews and $95 \%$ of the Arabs claimed that "humans were created by God, as opposed to a process of evolution."

The second point is that, in Israel, even after various reforms in the elementary and junior high school curricula, the topic of human evolution is still absent from the general curriculum, and no mention is made of humankind's origins and development as part of an evolutionary process. It is worth noting that, in the context of our study, due to the longstanding absence of the topic of evolution from Israel's official curriculum $[43,44]$, most graduates of the school system, in its various sectors, are relatively unfamiliar with the subject.

\section{Study Goals}

As explained above, the aim of the zoology course, on which this study is based, was to provide in-service teachers from various religious environments with scientific knowledge about evolution (including the evolution of Human).

Using an action-research approach, the aim of this study was to provide answers to two main questions.

During and following the implementation of ReCCEE practices in the zoology course:

1. Did learners who attended the course who were resistant to the theory of evolution modify their attitudes toward the theory and their willingness to learn about its central ideas?

2. What were the learners' views (secular or religious) on addressing the specific teaching practices during the course?

(The fact that these practices were ReCCEE-oriented were not mentioned explicitly to the learners.)

Despite the recommendations in the literature to use explicit discussions about the science-religion relationship in the classroom to address teachers' struggles in evolution teaching, including implementing Barnes and Brownell's (2017) ReCCEE framework [12], not many studies have explored such practices in situ. To our knowledge, studies that specifically explore the effectiveness of ReCCEE practices from the instructors' perspective through self-reflective processes (e.g., reflective action research) are missing. In this study, we investigated how the pedagogical decisions of two biology instructors throughout a full academic course contribute to the reduction in learners' resistance to learn about evolution, learners' respect for various conceptions toward the science-religion relationship and their own professional growth as educators. This study will contribute to the research by providing suitable and applicable tools for other biology teachers who wish to mitigate the challenges they face resulting from learners' religious-based resistance to learning about evolution. Despite its focus on the challenges of in-service science teachers in a Jewish Israeli setting, this study has international implications, since tensions between science and religion in the context of evolution can be found also among Christians and Muslims worldwide, and are well-documented in the literature [13]. 


\section{Methodology}

\subsection{The Context and Approach of the Study}

This study was conducted at a leading college of education in Israel, within the framework of a 60-h zoology course. The course was part of a formal program of in-service training for science teachers, consisting of 15 sessions spread out over one semester, and it was emphasized that the evolutionary approach to biology within the program was compulsory. The course focused on the development processes of living creatures throughout the evolutionary tree, from prehistoric insects to humans and other mammals. It consisted of a combination of lectures, class discussions and active observations of small animals. Concerning evolution, the course's main objectives were: (a) to develop the learners' understanding of the scientific theory of evolution; (b) to reduce the learners' expected resistance to the learning of evolution; and (c) to foster the learners' awareness of different, and even contradictory, approaches to this controversial topic.

An action research [45] was conducted by the authors, who are all experienced science teachers in post-secondary institutions and researchers in science education. The first and second authors had been teaching in-service teachers and pre-service teacher trainees about the theory of evolution for several years. The second author (referred to hereon as the "instructor") taught the zoology course, while the first author (referred to hereon as the "observer") observed and documented the sessions. The third author took part in the reflective discussions, the design and validation of the research tools and the analysis and interpretation of the data.

Throughout the course, for both ethical and methodological reasons, the course participants were explicitly made aware of all the stages of our action research. Since the course participants were in-service teachers but also students in a course, they will be referred to as the "learners". At the beginning of the course, we requested their agreement to participate in the study and told them explicitly about its objectives. We obtained their full consent to let the observer conduct observations throughout the course and to let us use the questionnaires and journals they filled out as data in the study. After surveying the learners' beliefs about evolution and religion toward the end of the first stage of the course (see stages below), we explained to them that during the course we plan to (a) explicitly address the issue of the science and religion relationship, including possible tensions among learners from different religious and cultural backgrounds, and (b) implement teaching strategies that specifically address learners' learning challenges that are related to differences in their cultural and religious backgrounds. Toward the end of the course, we requested the learners to assess the extent to which the different teaching practices we had employed had influenced their attitudes toward evolution. During our interviews with some of the learners, we referred specifically to the impact of the teaching practices implemented in the course on their scientific understanding, their worldview and their ability to respect differing viewpoints on this topic.

\subsection{Participants}

The learners who participated in the study comprised 18 in-service teachers, all of whom held teaching certificates in a non-scientific field and had been teaching science at the primary school level for several years without being qualified science teachers. Since all the learners agreed to participate in the research (see Section 4.3), they were all included in the study. This was beneficial since the 18 learners represent a variety of viewpoints regarding the relationship between science and religion in the context of evolution. At the beginning of the study, the learners were asked to identify themselves as belonging to one of the four sectors to which Israeli Jews usually belong: (a) secular, (b) traditional, (c) national-religious, and (d) ultra-Orthodox. Six of the learners (four females and two males) defined themselves as secular, four (two females and two males) as traditional, six (five females and one male) as national-religious, and two (females) as ultra-Orthodox. (These terms are clarified in Appendix A.) 
The secular and traditional learners were not expected to have problems with the study of evolution; however, this study assumed that it was the heterogeneity of the group that would provide the stimuli necessary to spark the involvement of learners in meaningful discussions.

Since action research is a methodology which endeavors to bring about changes by means of simultaneous action and research linked by critical reflection [45], both action (the development and elaboration of the course) and research (the collection and analysis of the data) will now be described.

\subsection{Procedure}

We referred to the ethical concerns by means of the following steps: First, the study, which was conducted in accordance with the Declaration of Helsinki, was approved by the Ethic Committee of the Kibbutzim College of Education before the zoology course began. Then, at the beginning of the course, we explained the goals of our action-research to the learners and asked them to participate in the study. We pointed out that participation in the study is voluntary, not connected to the assessment process of the course, and that maximal efforts will be made to ensure confidentiality and privacy. All the course participants agreed to participate in the study and filled their informed consent for inclusion before they participated in the study. Only from this point and on was data collected throughout the course.

\subsection{Development and Elaboration of the Course by Means of Action Research}

When it became obvious that some learners rejected the very idea of learning about evolution, it was decided to make a distinction between the scientific contents of the theory of evolution, on the one hand, which made no concessions to religious considerations, and the strategies of teaching, on the other hand, which took into consideration the feelings of the religious learners, as recommended by the ReCCEE practices.

The teaching of evolution was reframed in order to make it more palatable and acceptable to the religious learners, without any attempt to alter their religious faith and beliefs, but also without betraying the scientific character of the theory.

Firstly, in order to make the idea of evolution less threatening for those learners who felt that it contradicts their religious beliefs, we decided to introduce the term "evolution" into the course gradually, in three stages. As the course progressed, stage by stage, the learners would become more and more involved in the controversial issues, till they reached the crucial controversy about creation or the evolution of Human. The structure of the newly planned course, divided into the three stages, is summed up in Table 1, displaying the gradual introduction of principles of evolution

Secondly, not only would religion-based objections not be ignored, they would be openly and explicitly discussed and clarified. "Discussed" meant anything from arguing in favor or against some views to just "talking about" them, clarifying meanings, providing relevant knowledge, etc. The main idea was that open discussions about this controversial subject, in an academic setting, involving learners from various religious backgrounds, could provide an opportunity to enhance the learners' readiness and willingness to learn about various approaches to the origin and development of life, and foster an atmosphere of mutual respect that allows the voicing of different approaches and worldviews. Thirdly, the instructor and the observer would discuss reflectively what had happened in each meeting and make appropriate decisions concerning the following meetings.

The ReCCEE practices, which were embedded into the course and were aligned with the three stages and the development of the course, are also presented in Table 1.

Stage 1 : "Evolution without evolution", i.e., principles of the theory, without explicit use of the term evolution

This stage covered the first four lessons of the course. Its primary purpose was to develop the learners' motivation to learn, to foster a positive attitude toward the course and its scientific contents, to build the learners' trust in their instructor and to lay a proper foundation for the teaching of evolution in a relaxed atmosphere. With this in mind, and by means of inquiry-based, experiential learning 
about the characteristics of various animals, we put emphasis on both the cognitive-scientific and the affective aspects of the relationship between man and nature. We avoided the explicit use of the term "evolution" at this stage, even when teaching scientific principles and content that could have been simply explained using the concept itself. The instructor therefore had to be constantly alert and careful in her choice of words. Toward the end of this stage, the instructor used the "acknowledge" and "explore" ReCCEE practices as she surveyed learners' beliefs on evolution and religion.

Stage 2 : Darwin without explicit reference to Human

This stage covered lessons five through nine of the course. Dealing mainly with the beginnings and development of life, it addressed the theory of evolution in-depth in the context of animals. Darwin's personal story was to be used to introduce a preliminary discussion of the science-religion relationship (i.e., "provide role model" ReCCEE practice). Our assumption was that the conflicts he felt within himself between his religious beliefs and his scientific discoveries regarding the evolution of species would arouse the learners' intellectual interest, curiosity and empathy and, in turn, encourage those learners who were experiencing similar conflicts to learn about the theory of evolution and begin to envisage the possibility of combining religious faith with scientific thinking.

Stage 3 : "Evolution as evolution", with reference to humankind as an outcome of evolution

This stage covered the last five lessons of the course. Since the learners were expected to have reached a high level of interest and motivation to learn and an appropriate scientific background, they could now finally be confronted with the most controversial issue in the conflict over the theory of evolution, namely the origins of humankind. This final stage was to include the most extensive and explicit discussions about the tension between science and religion in the context of evolution. In this stage, all six ReCCEE practices were implemented (Table 1). The learners were to be confronted with the various approaches of Judaism to the relationship between religion and science, both generally and in the specific case of evolution. They were also expected to express a variety of opinions regarding the creation and development of life and to offer support for these opinions from various sources. The discussion about the possibility of combining scientific perceptions with religious faith was careful to remain respectful, non-judgmental and open to a full range of opinions.

Each stage was intended to correspond to one cycle in the action research, including all its components, as shown in Table 1. At the end of each cycle, we conducted reflective discussions in which we decided how best to proceed with the next one.

\subsection{Data Collection}

To describe learners' attitudes and responses to the contents and strategies of the course, we gathered data from several different research tools to gain a fuller picture and increase the validity and reliability of the findings [46]. Three tools (written questionnaires, personal journals and interviews) gathered the learners' testimonies about their own perceptions of what happened to them concerning their attitudes toward evolution. In addition, other tools (the instructor's reflective journal and the observer's in-class observations) referred to the perceptions of the teaching team.

1. The instructor's reflective journal and the observer's in-class observations

Throughout the course, the instructor and the observer noted their impressions, their points of hesitation and what they felt they had to think about, each from her own perspective. During stages 2 and 3 of the course (see Table 1), the specific questions, concerns and opinions that were expressed by the learners during the class discussions regarding the tension between science and religion were transcribed with precision. The observer watched all the lessons. This type of data, together with the learners' explicit feedback, were to fuel the critical discussions and pedagogical decisions and adaptations that were made from lesson to lesson. 


\section{Learners' questionnaires}

The pre- and post- open questionnaire included six straightforward questions about historical or geological events relevant to evolution: (a) What do you know about Charles Darwin? (b) What does the term "evolution" mean to you? (c) What do you find most difficult about accepting the theory of evolution? (d) How do you think the earth came into being? (e) In your opinion, did modern humans develop in an evolutionary process from earlier forms of humankind? (f) Do all animal species share a common source? Explain. These questions were based on questionnaires used in previous studies by various researchers $[8,21,40]$. The questionnaire reflects the "acknowledge" and "explore" ReCCEE practices.

\section{Learners' study journals}

Learners' journals were to provide us with continuous feedback on their main points of interest, as well as on any concerns, feelings of contradictions or conflicts that some of them were experiencing between the theory of evolution and their religious beliefs. We requested the learners to answer the following questions in writing after every lesson and to add any spontaneous comments they may regard to be useful feedback: (a) What scientific principles did I learn today? (b) What did I like about the lesson? (c) What was interesting or important in the lesson? (d) What would I like to understand in greater depth? (e) What was troubling, challenging or unclear? (f) What would I choose to apply in my own teaching?

4. In-depth interviews with selected learners

At the end of the course, we conducted semi-structured in-depth interviews [47] with six learners. Based on the contents of the learners' journals and questionnaires, we selected a sample of learners who represented the main types of learners in the course. The selected learners were asked to participate in the interviews on a voluntary basis. Six learners agreed to be interviewed. They represent a wide spectrum of conceptions toward evolution and evolution education. The interviews referred to (a) the learners' perceptions of the relationship between religion and science, mainly in the context of evolution, and to the status of the theory of evolution in their minds, (b) their willingness to incorporate the topic of evolution into their own teaching and (c) their opinion about the contribution of the course to the development of their perceptions and attitudes toward the theory of evolution focusing on the different ReCCEE practices and activities that were implemented throughout the course. Each interview was approximately sixty minutes long and was fully transcribed.

\subsection{Data Analysis}

The data were content analyzed according to the interpretive approach [48] to identify emergent categories and major themes focusing on the learners' perceptions of evolution and its learning and on the challenges of teaching this subject in the classroom. The data analysis included analysis of the learners' written responses, the transcriptions of the observations, the researcher's journal and the interviews. For validation of the analysis, we used the following process: First, each researcher coded the data independently. Second, a reflective dialogue between the researchers was conducted to discuss the codes and decide what citations would be the most suitable to use as evidence. This discussion was conducted until an agreement was achieved concerning the final categories. Third, the researchers invited an experienced researcher on the topic of teaching evolution in the Israeli education system for an additional reading of the chosen citations. This expert read our citations and agreed that most of them do reflect learners' perceptions of evolution and instructors' challenges to teach it.

\section{Main Findings}

The learners' attitudes are reported in the next sections, against the backdrop of classroom observations and discussions: The first section addresses our first research question and the second addresses the second research question. 


\subsection{Learners' Attitudes toward Darwin and Evolution Stage by Stage}

As could be expected, religious objections to evolution arose (see Table 2) by the national-religious and ultra-Orthodox learners, who were reluctant to answer questions about the conflict between science and religion, noting that they were not sure if they were "allowed" to answer questions that were actually blasphemous, since they contradict divine creation (see Table 2). In their view, religious faith and evolution were necessarily in contradiction. As mentioned above, these types of objections had, in fact, been the reason to divide the course into three stages of gradual introduction of evolution, and each stage brought with it characteristic objections and discussions which, in turn, led to specific pedagogical decisions.

Stage 1 : Teaching evolution without "evolution"- The beginning of the explicit discussion

The first topic we addressed in stage 1 was the age of the earth. Immediately after filling out the questionnaire, the learners were taught about the formation of the earth and the beginnings of life. When the instructor became aware of some ultra-Orthodox and national-religious learners' uneasiness, she opened the discussion with the question, "Who is disturbed by the issue of geological time?" This was met with varied explicit objections that gave rise to a heated discussion. The major objection was the disagreement of the religious learners about the age of earth. In light of responses such as "For us, the age of Earth is exactly 5777 years", the instructor chose to put emphasis on the following two points, as an outcome of the very first explicit open discussion of teachers' objections using the "outline spectrum of views" and "highlight potential compatibility" ReCCEE practices:

The attitude of Judaism toward scientific discoveries. The instructor proposed the idea that one of the strengths of Judaism is that it is open to scientific discoveries and knowledge, even when they appear to contradict the Scriptures, and does not dissociate itself from scientific knowledge. This argument alleviated some of the resistance, if not to the theory, at least to the learning of the theory. One national-religious learner, for example, expressed his agreement: “That's true, there are different interpretations and there are religious scholars and philosophers who discuss this issue. And even Maimonides was a doctor and a scientist, so even back then we had this approach in Judaism of not resisting science."

The opinions of religious scientists. The instructor pointed out that combining religious faith and scientific claims has been commonplace in various religious circles since the days of Maimonides, and that many religious scientists even accepted the theory of evolution. This clarification surprised some ultra-Orthodox and national-religious learners, who kept denying the possibility, while others displayed a tendency toward the interpretive approach (apparent contradictions result from misunderstandings of the Scriptures). For example, one national-religious learner quoted the following verse from Gen. Rabbah, 3:9 as a religious explanation for the reconciliation of the Scriptures with geological time and the extinction of prehistoric species: "Rabbi Abbahu said: Hence we learn that the Holy One, blessed be $\mathrm{He}$, went on creating worlds and destroying them until $\mathrm{He}$ created these [sc. heaven and earth], and then He said: "These please Me; those did not please Me". Another national-religious learner added his contribution to the discussion by noting that "a university professor told us that the 5700-year count from the divine creation of the world began only 4.6 million years after the formation of the earth."

To sum up, at this stage no one expected the religious learners to condone all the suggestions of the instructor or their peers: The objective of the action research was not to convince them otherwise, but to involve them in an explicit discussion about the topic of evolution, thus breaking the first barricade of resistance. 
Table 2. The various attitudes of the religious (Ultra-Orthodox and National-religious) learners at different stages of the course (UO-ultra-Orthodox; NR-national-religious).

\begin{tabular}{|c|c|c|c|}
\hline $\begin{array}{l}\text { Type and Number of Learners } \\
\text { Who Held the Attitude }\end{array}$ & Learners' Attitudes toward Evolution & Learners' Mind-Set & Stage of the Course \\
\hline $2 \mathrm{UO}$ & Denial of evolution, refusal to learn; & \multirow{2}{*}{$\begin{array}{l}\text { Arousal of curiosity about the possibility to combine } \\
\text { science and religion. }\end{array}$} & \multirow{2}{*}{$\begin{array}{l}\text { Starting point: Evolution "without evolution" } \\
\text { (The age of the earth) }\end{array}$} \\
\hline $5 \mathrm{NR}$ & No refusal to hearing about evolution. & & \\
\hline $2 \mathrm{UO}$ & Cannot accept evolution, but find Darwin's conflicts poignant; & \multirow[b]{2}{*}{$\begin{array}{l}\text { People like Darwin are not necessarily blasphemous } \\
\text { people to be rejected by society. They may undergo } \\
\text { similar conflicts to ours; } \\
\text { Need for a religious authority to corroborate the } \\
\text { possibility that science and religion may coexist. }\end{array}$} & \multirow[b]{2}{*}{$\begin{array}{c}\text { Darwin } \\
\text { (Own discoveries and dilemmas) }\end{array}$} \\
\hline $2 \mathrm{UO}, 6 \mathrm{NR}$ & $\begin{array}{l}\text { Willing to look further into the theory of evolution: } \\
\text { (a) If science and religion can coexist, then evolution may be } \\
\text { studied, but not necessarily believed. } \\
\text { (b) It is only a refutable theory. }\end{array}$ & & \\
\hline $1 \mathrm{UO}, 5 \mathrm{NR}$ & $\begin{array}{l}\text { Would like to believe, but still perceive a contradiction, and the } \\
\text { Torah cannot be wrong; }\end{array}$ & \multirow{6}{*}{ Curiosity toward undeniable and surprising facts. } & \multirow{6}{*}{$\begin{array}{l}\text { Evolution as evolution } \\
\text { (Humankind as an outcome of evolution) }\end{array}$} \\
\hline $6 \mathrm{NR}$ & Understand the scientific reasoning but cannot believe in it; & & \\
\hline $2 \mathrm{UO}, 4 \mathrm{NR}$ & $\begin{array}{l}\text { May study the theory, but believe that only religion can provide } \\
\text { answers to all the questions it raises; }\end{array}$ & & \\
\hline $1 \mathrm{UO}, 2 \mathrm{NR}$ & $\begin{array}{l}\text { Believe in biological adaptation, but refuse to see it as an } \\
\text { outcome of evolution; }\end{array}$ & & \\
\hline $1 \mathrm{UO}, 6 \mathrm{NR}$ & Evolution may be taught, but not in relation to humankind; & & \\
\hline $2 \mathrm{UO}$ & $\begin{array}{l}\text { The theory of evolution is pointless; Why should we challenge } \\
\text { the holy supremacy of man? }\end{array}$ & & \\
\hline $2 \mathrm{UO}, 5 \mathrm{NR}$ & $\begin{array}{l}\text { Appreciate the atmosphere of free discussion, but could never } \\
\text { implement it in their school classes; }\end{array}$ & \multirow{2}{*}{ Escapism or begging for help. } & \\
\hline $3 \mathrm{NR}$ & $\begin{array}{l}\text { Believe evolution should be taught at school, but would never } \\
\text { be allowed to. }\end{array}$ & & \\
\hline $2 \mathrm{UO}, 4 \mathrm{NR}$ & $\begin{array}{l}\text { Cannot adopt the theory of evolution, but would agree to study } \\
\text { it further. }\end{array}$ & & $\begin{array}{c}\text { End of the course } \\
\text { (After having learned about evolution) }\end{array}$ \\
\hline
\end{tabular}


Stage 2 : Learning about Darwin the person—exploration of Darwin's theory

Following the preliminary discussion, the learners were given the task of writing a short essay on the development of life (from bacteria to humankind), according to the scientific theory. The ultra-Orthodox learners expressed emotional difficulty with this task. For example, one of them told us, "As a religious woman who was not raised and educated according to this theory [evolution], I felt bad doing the work." The expression of that type of feeling, which had no relation to the logical aspects of the theory, led us to decide that at that point the learning of evolution should lean toward the emotional rather than the cognitive domain. Therefore, we decided to have the learners deal with "Darwin, the man and the researcher" to a greater extent than we had originally planned.

Instead of lecturing on Darwin's voyage, we decided to give the learners a task in which they write by themselves about Darwin's biography, focusing on the key events that led him to develop the theory of evolution. In this task, we implemented the "provide role models who accept evolution" and "highlight potential compatibility" practices. Following this task, we held an explicit discussion about the complexity of Darwin's character as both a devout Christian and a naturalist. This discussion focused on Darwin's personal struggles, and his perpetual reservations about publishing a theory that contradicted the position of the church. To foster the learners' empathy toward Darwin, the instructor told the learners:

I want you to see Darwin not as an enemy, but as a scientist-as a man who could not deny the significance of his findings and who was himself greatly troubled by their contradiction of the Old Testament... [furthermore] why did he delay [publication]? Did he remember that Galileo was forced to burn all his books? Even in Darwin's lifetime, the church was a powerful and frightening ruler.

In the spirit of the ReCCEE practice, "teach nature of science", inserting Darwin's personal narrative into the course demonstrated that personal issues could influence scientists' behavior and decision-making regarding scientific discoveries. By becoming aware of the moral dilemmas faced by Darwin as he developed the theory of evolution and wrestled with the idea of publishing it, the learners could be expected to develop empathy with him, thus reducing their socially rooted tendency to demonize Darwin as a person and, hopefully, increasing their readiness to refer to his theories.

The following words of an ultra-Orthodox learner appear to show that the strategy was somewhat successful:

All the facts we learned about Darwin as a person, the path that led him and the process he went through before developing the theory, these are things I never knew and they helped me because I believe that when you know characters and the story that lies behind the theory, this contributes a lot ... the story behind Darwin is an important element in understanding; no less important than the theory itself.

This strategy led the learners to understand that Darwin himself struggled for several years while seeking compatibility between his scientific findings and his own faith, which drew a parallel between Darwin's difficulties and those of the learners, and seemed to alleviate some of the remaining resistance to the learning of evolution.

Another type of virulent objection was rooted in the theory of "social Darwinism ("Social Darwinism" is a fallacious theory that draws a distorted parallel between the development of biological species as a result of interspecies competition on the one hand, and the development of social systems through competition between social groups on the other [49]. Social Darwinists, some of whom have been Prominent scientists, statesmen and academics, used a distorted interpretation of Darwin's theory to claim that artificial selection could (and should) be used to "improve the species" by promoting select groups of humans with more desirable qualities and reducing others with qualities that were unwanted [49].)". Several learners (mainly the ultra-Orthodox) claimed that since Hitler had used the theory of evolution in the development of his race theory, Darwinism had led to the 
Holocaust (see Appendix A). When this argument arose during the discussion of Darwin's life, we decided to introduce the learners to Darwin's own social views regarding the status of various human "races". For example, we emphasized the strong objections of Darwin and his family to slavery, and to the hierarchical division of humankind into separate groups. The ultra-Orthodox learners seemed surprised to learn that the claim that Darwin's theories could serve as a basis for racist theories was essentially flawed. The following quote from an ultra-Orthodox learner exemplifies the shift in her position toward Darwin, the man (though not, ultimately, toward his theory) at the end of the course:

Darwin was an interesting man, driven, thorough and creative, who-if it was not for the fact that the biblical version cannot be denied-might challenge me to look further into his theory and his biography, and to compare it with alternative theories.

Still, near the end of stage 2, some religious (national and ultra-Orthodox) learners remained frustrated by what they continued to regard as contradictions between the scientific narrative of the evolutionary processes and the biblical story of creation. In their eyes, we could not be considered reliable authorities on this topic. Therefore, after consulting with two peer scientists from religious teacher training colleges, we decided to invite, as a guest lecturer, a national-religious scientist who specializes in the training of religious and ultra-Orthodox science educators in a religious college. We asked her to confront the learners with a spectrum of viewpoints on religion and evolution. The guest lecturer presented different types of science-religion relationships that exist in Judaism, described how evolution is perceived in each type, and explained how she, as a national-religious person and a scientist, managed to perceive both religion and evolution as acceptable and non-contradictory. The lecture resulted in a lively discussion between the guest lecturer and the learners.

Providing a religious role model that accepts evolution was quite effective. All the learners referred to the lecture as an important milestone in the course, but not all of them for the same reasons. For some of the national-religious and the traditional learners, the lecture confirmed the idea that the scientific facts they were learning in the course could be combined with their religious faith without necessary contradiction, and that scientific and religious views can coexist. For example, one national-religious learner said:

I found the lecture fascinating. It really expanded my understanding of the many interpretations that exist and the different approaches in Judaism to science and evolution ... I felt that it tied up a lot of loose ends for me and gave me answers to questions that had troubled me as a result of taking this course.

In the same vein, another national-religious learner said, "As a religious person, I found it fascinating to learn about evolution from a lecturer who comes from the religious world." Other learners noted that the lecture had widened their perspective about the relationship between science and religion and provided them with a variety of possible solutions to a conflict with which they now found that they could live. Others, however, found comfort mainly in a controversial interpretation of one of the guest's statements, namely that like all scientific theories, evolution was essentially refutable, not absolute truth, so that one does not have to believe it.

It is worth mentioning that the response of secular learners also displayed interest. As one of them pointed out, "The lecture was important because it explicitly addressed the inherent religious conflict between science and religion over the theory of evolution, and the lecturer also suggested a number of different ways of resolving that conflict".

However, the (national) religious role model was less effective among the strictly religious ultra-Orthodox learners, who expressed strong resistance to any approach that claims that science and Torah can co-exist on the basis that they do not overlap. One of the ultra-Orthodox teachers claimed heatedly, "The Torah is eternal, it is infinite, it is impossible to separate ... it encompasses everything, it is total and there is no part of life to which it is not connected." Still, it is worth noting that this refusal to accept was part of a discussion that happened after the ultra-Orthodox learners had listened to the presentation of the guest lecturer. 
Stage 3 : Humankind's origins: reaching new heights? Climbing the evolutionary scale

The third stage of our action research (see Table 1), speaking about the blasphemous idea of evolution of humankind, was the ultimate destination of the course. This is, as shown above, the area in which there appears to be no possible compromise. In light of the earlier discussions, it was clear to us that we needed to find appropriate teaching strategies that would allow us to focus on the scientific conception of the origins of humankind by choosing and using the most effective ReCCEE practices and activities to best assist learners to manage science-religion tensions. Moreover, in light of the empathy that the learners had felt toward Darwin as a researcher at the end of stage 2, we again chose to focus on stories of scientific discoveries through the eyes of scientists, focusing on building knowledge in science (as part of the nature of science) against a backdrop of historical discoveries.

We therefore opened this stage of the course with a narrative of scientific discoveries about the development of humankind from the first hominids to modern hominoids; for example, the revolutionary discovery of "Lucy", the Australopithecus. The course focused on the personal stories of the researchers, on their experience of discovery, and on the winding roads that led to their revolutionary findings. We realized that this practice was useful for the teachers. Even the religious learners, regardless of their level of religious faith, were captivated by the topic. As one national-religious learner said, "Lucy was a totally new subject! I didn't know anything about her. It's amusing, fascinating and exciting, and sparks the imagination ... humankind is the most fascinating topic because it relates to us".

Some of the religious learners, regardless of their level of religiosity, noted explicitly that learning about the evolution of humankind would lead them to continue exploring the topic independently - to understand it better themselves and also to teach it to their students. For example, a national-religious learner said:

The topic of human evolution is very interesting, I could look into it more and more ... it [also] fascinated my students, the idea that we weren't always like we are today. As far as they were concerned, we were always like this!

It seems that, again, choosing to focus on stories related to scientific discoveries (and to aspects of the nature of science) elicited the empathy of the learners, which alleviated their resistance to learning about the controversial scientific approach to the origins of humankind.

The learners' journals revealed that the ReCCEE strategies that we chose to embed into the classroom in stage 3 of the course had a crucial impact on their understanding of the theory of evolution. All of them understood the scientific idea that humankind developed in stages from the original ancestor to the modern human. For some, this understanding reinforced their acceptance of evolution. For others, however, understanding this issue did not entirely prevent the rejection of the theory. For example, a national-religious learner stressed, "The course made me accept the theory of evolution from the scientific side, but I still have difficulties ... the creation of man remains foggy to me". Another national-religious learner indicated: "I accept evolution ideas until it comes to humankind-in relation to humans, I do not accept it". An ultra-Orthodox learner said, "I still find it difficult and disturbing to think that humans developed out of apes"; A national-religious learner went further: after understanding the theory of evolution and finding it unsatisfactory, she stated, “Before, I wasn't able to say anything about evolution because I had never learned about it. The course encouraged me to learn about it, which strengthened my religious faith because only in religion do you have answers for everything."

Concerning teaching evolution in their schools, all the religious learners (national and ultra-Orthodox) indeed remained cautious. While admitting their own change of attitude toward the theory of evolution, they noted that they could integrate into their teaching only the components of the theory of evolution that are compatible with Judaism. For example, one ultra-Orthodox learner explained that she would teach evolution only when it does not challenge the timeline of creation, and would focus on natural selection only in the context of single species: 
I won't go into evolution because the timelines don't match up. However, "light" evolution like bacteria that develop and evolve quickly in response to antibiotics, or in humans, where inside the species there are "types" with different eyes and different colored skin that makes sense as evolutionary adaptations to the environment. You can see the adaptations today that have occurred over 6000 years, although they didn't turn into another species. That's a change and a development that I can teach.

A big issue was the attitude of the national-religious school sector. A national-religious learner who had expressed her willingness to teach about evolution stressed that she doubted the possibility of actually doing it because of constraints imposed by the school:

I'm ashamed to tell you that two years ago a child asked me in class if dinosaurs existed, and I didn't know what to tell him. I couldn't get it out of my mouth that they really did. I also didn't really know. Today, after the course, I have a completely different attitude. If they ask me about dinosaurs, I'll have lots to say! What we learned I can teach happily, and I would really like to, but I'm not sure I'm allowed to in the school where I teach, which is religious. In a secular school I would teach it gladly.

Such feelings were also clearly expressed by one of the ultra-Orthodox learners:

I feel so much at ease with you that I feel I can share [my feelings] .... When I was doing the homework, it was very hard for me to accept the theory of evolution .... As a religious woman, who was not raised and educated according to this theory, I felt bad writing a paper the contents of which I would never be able to use.

The ultra-Orthodox learners felt somewhat disoriented and distressed by the strength of the conflict they perceived between science and religion in the context of the origins of humanity. One of them asked, "Do you think I can believe in only part of evolution? ... I believe in the mathematical-scientific part of evolution, and only to a limited extent, as long as it fits in with my [religious] truths ... not the part about humans."

Another ultra-Orthodox learner stuck adamantly to the philosophical-religious position that she held at the beginning of the course and felt that the inclusion of the ReCCEE practices during her learning about evolution was pointless. Even after learning about evolution, she said, "I really don't understand why we should teach, learn and research this? Humanity is sacred and the Torah is sacred. Why should we bring man down from his supremacy? After all, everything was created for him."

To sum up, we found that using various ReCCEE practices in the three stages of the course increased some previously "resisting" ultra-Orthodox and national-religious learners' willingness to learn about the scientific principles of evolution and even to include them in their own teaching, albeit in varying degrees and with various reservations. The learners' responses also suggested that they had appreciated the freedom to express their views about various, sometimes extreme, challenges of learning or teaching about evolution. They felt that after having been confronted with a range of opinions regarding the development of species and the origins of humankind, they were more willing, or able, to respect points of view that stood in contrast to their own. However, most of the reservations of the ultra-Orthodox and national-religious learners concerning the theory itself remained at the end of the course as tenacious as at its beginning. The various attitudes and arguments of religious learners throughout the stages of the course are shown in Table 2. The number of expressed attitudes presented in Table 2 is greater than the number of learners, because attitudes evolved along the three stages of the course, so that each learner could express more than one attitude.

\subsection{Learners' Views about the Teaching Practices Implemented in the Course}

Data from the learners' interviews and journals suggest that all the learners appreciated our decision to explicitly address the conflict between science and religion. They showed that they appreciated the instructor's "vigilance toward the dynamics that result from cultural differences" ([14], p. 294), 
and her readiness "to acknowledge the existence of diverse perceptions amongst students" [16,17] using various ReCCEE strategies. Firstly, teaching about evolution while acknowledging that some learners may see a conflict between evolution and their religious beliefs, and encouraging them to explore their own view by providing knowledge about the theory and its relation to religion, allowed learners to build an attitude based on knowledge instead of ignorance. For example, a national-religious learner said:

The course changed a lot for me. I didn't know about natural selection or mutations or fossils, or about all the scientific data. And I also didn't know what the religion's attitude toward learning this was. Years ago, it seemed like heresy to learn and talk about it, and what I knew about was negative and non-accepting attitudes. In this course, I learned about it in depth, both the scientific theory and its relation to religion. Today, I really accept it from a position in which I understand the scientific approach to the subject.

Secondly, learners appreciated the fact that the open discussions accounted with equal respect for the whole range of perspectives on the science-religion issue that were unveiled during the course. A national-religious learner claimed:

This approach improved my scientific understanding and changed my attitude toward learning about evolution. Everything I went through in this course-and I went through a lot-was due to the instructor's sensitivity and her approach of understanding the other person's position, and that's what really got me to change. It's all about how the course was taught: gradually, with positive attitudes.

Thirdly, a few religious (mainly national) and traditional learners expressed their appreciation of the fact that the instructor did not try to convince them that a particular approach was the "right" one. In other words, acknowledging the diversity in learners' positions regarding science-religion connections and presenting a spectrum of viewpoints regarding evolution and religion without taking a position of what is more correct were highly appreciated by the learners, as one of the national-religious learners indicated:

The issue of Torah vs. science is troubling sometimes, but here [in the course] nothing was imposed, and everyone chose their own way ... some of the things were very provocative, but everyone can do with these things what they find appropriate and as their Rabbis command.

Furthermore, in their interviews, learners stated that some of the ReCCEE practices had increased their readiness to incorporate topics related to evolution in their own teaching because discussions had provided them with tools to handle students' various opinions on this topic. In this context, we found a direct and expected connection between the learners' religiosity and their willingness to teach about evolution. The secular learners noted that, following the course, they would consider teaching the theory "as a whole", while explicitly addressing the science-religion conflict to which the course had exposed them. For example, one secular learner, who had already begun integrating evolution into her teaching as the course progressed, addressed how her exposure to the spectrum of viewpoints of evolution and religion assisted her as a teacher:

Now I know there is a population that rejects evolution .... As a teacher it is now much easier for me to convey [to students] the conflict between science and religion ... a fifth grader told me, "My grandfather doesn't believe in evolution", and that's something I need to acknowledge ... the lessons and discussions that arose in the course gave me examples of how to behave with the children when they raise questions about Genesis vs. evolution and science ... this year in fifth grade, after taking this course, I taught them about dinosaurs and they asked me how that works out with the ... [biblical] timeline for the creation of the earth, and for the first time, I was able to explain the two approaches-scientific and religious. 
It is worth noting that this learner's participation in the open discussions had made her aware of the need to address the various objections, opinions and attitudes that students bring with them to the classroom.

Interestingly, the secular learners stated that exploring their own views and their peers' views of evolution and their relation to religion had been very significant to them, in spite of the fact that they had not felt a priori any conflict in relation to evolution. As noted in the instructor's journal, it made the course more interesting, allowed learners to get to know the varied perspectives of their peers, and gave them an opportunity to address the science-religion conflict in the context of evolution. This is exemplified in the following quotes from two secular learners:

You can't, at this point in history, avoid the discussion of religion vs. evolution. It's very important for people to express their difficulty with this issue and find a way to reconcile the two.

The scientific and philosophical discussions in the lessons devoted to Darwin and evolution made the lessons exciting and interesting. Presenting different approaches that attempt to "solve" the conflict between religion and evolution was important and new for me. The discussion was specifically interesting because it revealed the emotional impact of this issue and the different ways in which different learners approach it.

Altogether, the learners' responses showed that, due to the open discussions, they felt that they had learned about differing views of the theory of evolution, including its controversial aspects, and had also been provided with methods that might enable them to cope with the conflicts. They also showed that the explicit discussion method had overcome most of the resistance to learning about evolution—although not necessarily believing in it—and that the teachers had appreciated not only the contents of the course, but also the teaching strategy.

\section{Discussion and Conclusions}

Before discussing the outcomes of this study, some of its specific aspects should be evoked. First, concerning the sample, the ultra-Orthodox learners did not volunteer to study the evolution of humankind. Metaphorically, they did not represent a population of people who came to the watering place in order to taste the water, but one of people who were led to the watering place and then refused to drink or taste the water. This was also true to some extent concerning the ultra-Orthodox-religious participants, who came for in-service training in a secular college, showing that they were ready to cooperate with a mixed population. It should also be remembered that the course was a compulsory part of the program. Conclusions from this study should account for the special characteristics of the sample.

Secondly, regarding the purpose of the course, the instructor made no effort to make the ultra-Orthodox learners give up their religious beliefs. She aimed to make them aware of the scientific nature of the theory of evolution and its development by listening to an account of it. Thirdly, concerning the teaching strategy, a strong emphasis was placed on the distinction between the scientific contents of the course, which made no concessions to religious claims or beliefs, and the teaching strategy, which took into account the feelings of the religious learners. Finally, this study is not to be regarded as an experiment in the application of the ReCCEE framework. Its ideas and practices were found to closely meet the requirements of the course and this study, so they are given full credit in this paper, although as there was no commitment to adhere totally to ReCCEE, some activities may not conform exactly with its definitions.

Since the religious (national and ultra-Orthodox) learners struggled to study the theory, claiming that, in their view, it was extremely controversial and even false and blasphemous, religion had to be taken into account-if not as a part of the theory, at least as a part of the teaching strategy. Furthermore, since the obstacle to the teaching of evolution was the resistance of religious learners, the teaching strategy, which was designed to overcome or alleviate this resistance, had to focus primarily on the 
religious learners. The secular and traditional learners in any case found it to be quite agreeable and adequate, and appreciated the contribution of open discussions, emphasizing that these discussions increased their own awareness to others' perceptions regarding evolution.

Was the strategy of the course successful? Were its objectives achieved, namely the learning of the theory and the development of an atmosphere of mutual respect? Did the learners appreciate the ReCCEE teaching strategy? Several practices, based on ReCCEE, were found to be useful. These included providing the religious learners with a role model who copes successfully with her religious beliefs and the ideas of evolution, creating learners' empathy for Darwin on a personal level, enabling learners with different perceptions of the science-religion relationship in the context of evolution to express their worldviews, and fostering an atmosphere of mutual respect for such views in a culturally diverse classroom. The main achievement was that the liberal and relaxing atmosphere created by the type of ReCCEE practices made possible the teaching of evolution-even human evolution-within a group of culturally diverse and antagonistic participants (secular, traditional, national-religious and ultra-Orthodox). The very fact that the instructor and her team found a way to make such an endeavor realistically feasible appears to display an improvement in cultural competence.

As shown above, while summing up the findings concerning the three stages of the course, we found that it had increased the willingness of some previously "resisting" learners to learn about the scientific principles of evolution or even to include them in their own teaching, although in varying degrees and with various reservations. The learners' responses also suggested that they had appreciated the instructor's teaching practices, especially the freedom to express their views about various challenges of learning or teaching about evolution, and that they were more willing or able than before the course to respect points of view that stood in contrast to their own. They also appreciated the fact that their views, while freely expressed, and often competing with scientific claims, were never explicitly contradicted or challenged by the instructor herself. The explicit discussions had clearly been enjoyed and apprehended as fruitful by the participants.

However, in spite of their interest in the history of the theory and of related empiric discoveries (e.g., from the biography of Darwin to Lucy), most of the religious learners kept their reservations and feelings of uneasiness about the conflict between the Holy Scriptures and the idea of human evolution. At some stage, they found themselves confronted with an acute problem, and this problem was not a scientific one: how to find practical solutions which would make the learning of evolution possible, when it was not absolutely prohibited by the local or national rabbinical establishment and not in contradiction to their own beliefs (e.g., time scales, status of humankind, teaching only part of the theory).

Even toward the end of the course, the feelings of most of the religious learners remained clear: learning about evolution as a scientific theory was indeed an attractive experience, especially in an atmosphere of open discussion. However, the idea of fully adopting the theory, or accepting it as possible, stood against formidable odds, somewhere on a scale between forbidden and impossible, and likewise the idea of teaching it at school. It follows that in order to be able to learn or teach in any way about evolution, the religious learners had to be reassured that such a behavior could be morally justified. Such a reassurance was partly provided by the invited (national-religious) scientist, who explained that being a scientific theory, evolution was essentially "refutable". The religious learners then felt that since evolution was regarded to be a theory and not an absolute truth, they had no obligation to accept it or believe it, compared to the absolute truth of the Torah's narrative of creation. In view of Popper's [50,51] claim that refutability is what makes a theory scientific, the reaction of the learners may be regarded by the scientific community as unfortunate, but it unveiled their feelings: they welcomed arguments that may allow religious people to study or teach evolution.

The term "believe" used by religious learners was also controversial because its meaning in the language of the learners did not correspond to that of scientists. Scientists may "believe" in a theory because, in their opinion, it represents a valid logical inference from empirical data, although it remains open to criticism. Religion, on the other hand, requires a theory to conform to absolute, 
immutable, a priori beliefs [52]. The clash between these two attitudes was obviously ever present in our course about evolution. Reassurance about religious beliefs can hardly be regarded to be an expected achievement of a scientific course. This is where we introduce the Hebrew word "dayenu", which literally means "We content ourselves with what we have". Ultimately, in the context of the study, there is only so much a single academic course can do to cope with the worldviews of religious students. Such worldviews have been shown in previous studies to be extremely resilient, and the teaching of evolution can have only a partial effect on the shaping of students' perceptions [53]. However, even if not all the learners of this course accepted the theory of evolution as possible truth, all of them were led to study evolution in a purely scientific context, and came to respect people who held opinions different from their own and to appreciate the opportunity to freely express their own opinions. So, from the point of view of this study, "dayenu".

Although evidence from our findings displays clearly the impact of the ReCCEE practices on the attitudes of religious learners towards evolution and evolution learning and on learners' appreciation of these practices, one should consider the limits of this study. The eighteen participants from the four different groups can not represent the full spectrum of viewpoints of religious learners regarding the tensions between science and religion in the context of evolution and evolution education. Further research with larger numbers of secular and religious participants in other contexts of teacher education programs could add to the full picture. Additionally, despite the positive atmosphere that was created by the instructor during the course, which encouraged the learners to share their thoughts and concerns regarding the theory of evolution and regarding learning or teaching about it, we can not be sure that all the students who felt discomfort with evolution fully expressed their feelings and viewpoints. Furthermore, considering that the instructor's attitude concerning evolution and its central role in understanding biological processes was well known to the learners, it might be that several religious students preferred not to share their thoughts despite the instructor's invitation to do that. However, the authenticity of the students' reactions and of their reported attitudes provide deep insights into the topic of this study.

Although this study was conducted in the context of a heated socio-scientific contest, in a country where religion is a ubiquitous social presence, its findings may be relevant to many other countries in which tensions between science and religion exist in the context of evolution and evolution teaching, such as the United Kingdom [54,55], Turkey [56,57], the United States [58,59]. The findings may also be relevant to other, less emotion-laden issues in which scientific knowledge appears to clash with deep-rooted traditional values, as in socio-scientific issues about nutrition, health, family planning, environment, etc. [60,61]. Careful, gradual introduction of relevant scientific developments and their implications, and avoiding provocative topics as much as possible, as well as a liberal "let's talk about it" atmosphere, encompassing various approaches and emotional aspects, as exemplified in this study, may lead even highly prejudiced people to be more accepting of scientific facts and theories, even if their implications may be quite disturbing from the point of view of established traditions, or social or political constraints.

Author Contributions: I.A., M.S. and A.D. built the conceptualization and theoretical framework of the study; I.A. and M.S. developed the methodology, and collected and analyzed the data; A.D. validated the qualitative analysis; I.A., M.S. and A.D. interpreted the findings, and prepared and edited the original draft of the paper. All authors have read and agreed to the published version of the manuscript.

Funding: This research was funded by the research authority of Kibbutzim College of education, Technology and the Arts in 2017.

Acknowledgments: The authors thank the participants for their agreement to take part in this study and for the rich data they provided. Kibbutzim College of Education Technology and the Arts is thanked for its financial support for the editing process.

Conflicts of Interest: The authors declare no conflict of interest. 


\section{Appendix A. Explanation of the Main Religious Sectors in Israeli Jewish Society}

The life of a religious Jew is regulated by the Halacha (Halacha (literally, "the way to behave") is the collective body of Jewish religious laws based on Written and Oral Torah.), a body of Jewish religious laws derived from the Written and Oral Torah, based on 613 divine precepts or commandments (mitzvot, singular: mitzvah), and on subsequent talmudic and rabbinic laws and traditions. The more strictly a Jew adheres to the Halacha, i.e., lives according to its commandments, the more religious he/she is regarded to be. The "ultra-Orthodox" community endeavor to adhere fully to the Halacha and to perform all its commandments. In order to be able to maintain their ritual lifestyle, they tend to live and work in segregated (although not isolated) communities or neighborhoods (villages, towns, or quarters in towns) and they mostly abstain from participating in civic state duties, such as military or national service. Their children learn in ultra-Orthodox schools within the framework of an independent school system, the curriculum of which is entirely independent from the state curriculum's requirements. Scientific contents in these schools are taught in a way that will not contradict the Halacha [62].

Members of the "national-religious" sector are believers who adhere strictly to a great number of the essential commandments of the Halacha. However, they are generally not physically, socially and culturally separated from the secular Israeli society: they take part fully in the life and civic activities of the state, serve in the army, may live in mixed neighborhoods, and work and study amongst other, less religious, citizens. Their children learn mostly in state religious schools, which depend on the national Ministry of Education. A full science curriculum, which includes some adaptations to the religious worldview, adopts the idea that science does not contradict religion and that science education even provides an opportunity to strengthen students' religious faith [63].

"Traditional" is a term that generally refers to people who display a limited degree of commitment to religion, but who choose, for personal, affective or social reasons, to keep observing some practices-like observing the Sabbath and eating only kosher food-that they recognize as central to Jewish life. They do not usually live in segregated religious neighborhoods; they may send their children either to a state secular school, or to a state religious one.

The lifestyle of the "secular" sector is not regulated by the Halacha. These people identify themselves culturally as Jewish, but do not practice the Jewish religious commandments. They send their children to state secular schools, the curriculum of which is designed centrally by committees of the Ministry of Education.

\section{References}

1. Coyne, J.A. Why Evolution Is True; Viking: New York, NY, USA, 2010.

2. Dobzhansky, T. Nothing in biology makes sense except in the light of evolution. Am. Biol. Teach. 1973, 35, 125-129. [CrossRef]

3. Lombrozo, T.; Thanukos, A.; Weisberg, M. The importance of understanding the nature of science for accepting evolution. Evol. Educ. Outreach. 2008, 1, 290-298. [CrossRef]

4. Abrie, A.L. Student teachers' attitudes towards and willingness to teach evolution in a changing South African environment. J. Biol. Educ. 2010, 44, 102-108. [CrossRef]

5. Goldston, M.J.; Kyzer, P. Teaching evolution: Narratives with a view from three southern biology teachers in the USA. J. Res. Sci. Teach. 2009, 46, 762-790. [CrossRef]

6. Fowler, S.R.; Meisels, G.G. Florida teachers' attitude about teaching evolution. Am. Biol. Teach. 2010, 72, 96-100. [CrossRef]

7. BouJaoude, S.; Asghar, A.; Wiles, J.R.; Jaber, L.; Sarieddine, D.; Alters, B. Biology professors' and teachers' positions regarding biological evolution and evolution education in a Middle Eastern society. Int. J. Sci. Educ. 2011, 33, 979-1000. [CrossRef]

8. Gallup. Evolution, Creationism, Intelligent Design. 2017. Available online: http://news.gallup.com/poll/ 21814/evolution-creationism-intelligent-design.aspx (accessed on 16 October 2020). 
9. Ecklund, E.H.; Scheitle, C.P. Religion among academic scientists: Distinctions, disciplines, and demographics. Soc. Probl. 2007, 54, 289-307. [CrossRef]

10. Graffin, G.W.; Provine, W.B. Macroscope: Evolution, religion and free will. Am. Sci. 2007, 95, $294-297$. [CrossRef]

11. Orin, T.; Frankel, R.; Ziv, S. What happened to the teaching of evolution? J. Biol. Teach. 2001, 166, 18-31. (In Hebrew)

12. Barnes, M.E.; Brownell, S.E. A call to use cultural competence when teaching evolution to religious college students: Introducing religious cultural competence in evolution education (ReCCEE). CBE-Life Sci. Educ. 2017, 16, 1-10. [CrossRef]

13. Barnes, M.E.; Brownell, S.E. Practices and perspectives of college instructors on addressing religious beliefs when teaching evolution. CBE-Life Sci. Educ. 2016, 15, 1-19. [CrossRef]

14. Betancourt, J.R.; Green, A.R.; Carrillo, J.E.; Ananeh-Firempong, O. Defining cultural competence: A practical framework for addressing racial/ethnic disparities in health and health care. Public Health Rep. 2003, 118, 293-302. [CrossRef]

15. Tanner, K.; Allen, D. cultural competence in the college biology classroom. CBE Life Sci. Educ. 2007, 6, 251-258. [CrossRef]

16. Reiss, M.J. Should science educators deal with the science/religion issue? Stud. Sci. Educ. 2008, 44, 157-186. [CrossRef]

17. Shane, J.W.; Binns, I.C.; Meadows, L.; Hermann, R.S.; Benus, M.J. Beyond Evolution: Addressing Broad Interactions Between Science and Religion in Science Teacher Education. J. Sci. Teach. Educ. 2016, 27, 165-181. [CrossRef]

18. Meadows, L.; Doster, E.; Jackson, D.F. Managing the conflict between evolution and religion. Am. Biol. Teach. 2000, 62, 102-107. [CrossRef]

19. Cannard, K. Embracing controversy in the classroom. Sci. Scope 2005, 28, 14-17.

20. Baker, J.O. Acceptance of evolution and support for teaching creationism in public schools: The conditional impact of educational attainment. J. Sci. Stud. Relig. 2013, 52, 216-228. [CrossRef]

21. Hokayem, H.; BouJaoude, S. College students' perceptions of the theory of evolution. J. Res. Sc. Teach. 2008, 45, 395-419. [CrossRef]

22. Sikkink, L. Teaching evolution as a cultural anthropologist: Student perception of evolution at Western State College. Gen. Anthropol. 2009, 16, 8-12. [CrossRef]

23. Downie, J.R.; Barron, N.J. Evolution and religion: Attitudes of Scottish first year biology and medical students to the teaching of evolutionary biology. J. Biol. Educ. 2000, 34, 139-146. [CrossRef]

24. Diller, J.V.; Moule, J. cultural competence: A Primer for Education; Thompson Educational Publishing: Toronto, ON, Canada, 2005.

25. Nadelson, L.S.; Hardy, K.K. Trust in science and scientists and the acceptance of evolution. Evol. Educ. Outreach 2015, 8, 1-9. [CrossRef]

26. Brickhouse, N.W.; Dagher, Z.R.; Letts, W.J., IV; Shipman, H.L. Diversity of students' views about evidence, theory, and the interface be tween science and religion in an astronomy course. J. Res. Sci. Teach. 2000, 37, 340-362. [CrossRef]

27. Winslow, M.W.; Staver, J.R.; Scharmann, L.C. Evolution and personal religious belief: Christian university biology-related majors' search for reconciliation. J. Res. Sci. Teach. 2011, 48, 1026-1049. [CrossRef]

28. Scharmann, L.C.; Butler, W. The use of journaling to assess student learning and acceptance of evolutionary science. J. Coll. Sci. Teach. 2015, 45, 16-21. [CrossRef]

29. Dodick, J.; Dayan, A.; Orion, N. Philosophical approaches of religious Jewish science teachers toward the teaching of 'Controversial' topics in science. Inter. J. Sci. Educ. 2010, 32, 1521-1548. [CrossRef]

30. Nehm, R.H.; Schonfeld, I.S. Does increasing biology teacher knowledge of evolution and the nature of science lead to greater preference for the teaching of evolution in school? J. Sci. Teaching Teach. Educ. 2007, 18, 699-723. [CrossRef]

31. Martin-Hansen, L.M. First-year college students' conflict with religion and science. Sci. Educ. 2006, 17, 317-357. [CrossRef]

32. Barnes, M.E.; Elser, J.; Brownell, S.E. The impact of a short evolution module on students' perceived conflict between evolution and religion. Am. Biol. Teach. 2017, 79, 104-111. [CrossRef] 
33. Southerland, S.A.; Scharmann, L.C. Acknowledging the religious beliefs students bring into the science classroom: Using the bounded nature of science. Theory Pract. 2013, 52, 59-65. [CrossRef]

34. Glaze, A.L.; Goldston, M.J. US science teaching and learning of evolution: A critical review of the literature 2000-2014. Sci. Educ. 2015, 99, 500-518. [CrossRef]

35. Lindsay, J.; Arok, A.; Bybee, S.M.; Cho, W.; Cordero, A.M.; Ferguson, D.G.; Jensen, J.L. Using a reconciliation model leads to large gains in evolution acceptance. CBE-Life Sci. Educ. 2019, 18, 1-11.

36. Ferguson, D.G.; Mann, M.; Cordero, A.M.; Jensen, J.L. Reconciling evolution: Evidence from a biology and theology course. Evol. Educ. Outreach 2020, 13, 1-8.

37. Lerner, S. Good Science, Bad Science: Teaching Evolution in the States; The Thomas B. Fordham Foundation: Washington, DC, USA, 2001.

38. IPSOS MORI, BBC Survey on The Origins of Life. 2006. Available online: https://www.ipsos.com/ipsos-mori/ en-uk/bbc-survey-origins-life (accessed on 16 October 2020).

39. Dawkins, R. The Greatest Show on Earth; Free Press: New York, NY, USA, 2009.

40. Pew Research Center on Religion and Public Life. Public Divided on Origins of Life. 2013. Available online: http://www.pewforum.org/2013/12/30/publics-views-on-human-evolution (accessed on 16 October 2020).

41. Eurobarometer. Europeans, Science and Technology. European Commission. 2005. Available online: http://lms.lt/archyvas/files/active/0/ebs_224_report_en.pdf (accessed on 16 October 2020).

42. Yaar, E. Science and Technology in the Israeli Consciousness. Haifa Israel: Samuel Neaman Institute. 2006. Available online: https://www.neaman.org.il/Science-Technology-in-Israeli-Consciousness-HEB (accessed on 16 October 2020). (In Hebrew)

43. Tsezna, R. Evolution teaching: Why and how? Kriat Benaim 2014, 22-23, 22-32. (In Hebrew)

44. Asher, I. The School Curriculum in Evolution Education in Israel and Worldwide; Ministry of Education, Chief Scientist: Jerusalem, Israel, 2015. Available online: http://meyda.education.gov.il/files/Scientist/ evolution.pdf (accessed on 16 October 2020). (In Hebrew)

45. Zeichner, K. Educational action research. In Action Research-Participative Inquiry and Practice; Reason, P., Bradbury, H., Eds.; Sage: London, UK, 2001.

46. Eliott, J. Action Research for Educational Change; Open University Press: Bristol, PA, USA, 1991.

47. Fontana, A.; Frey, J.H. The interview. From structured questions to negotiated text. In Handbook of Qualitative Research, 2nd ed.; Denzin, N.K., Lincoln, Y.S., Eds.; Sage Publication: Thousand Oaks, CA, USA, 2000; pp. 645-672.

48. Strauss, A.; Corbin, J. Basics of Qualitative Research: Techniques and Procedures for Developing Grounded Theory; Sage Publications: Washington, DC, USA, 1998.

49. Hawkins, M. Social Darwinism in European and American thought, 1860-1945: Nature as Model and Nature as Threat; Cambridge University Press: Cambridge, UK, 1997.

50. Popper, K. Natural selection and the emergence of mind. Dialectica 1978, 32, 339-355. [CrossRef]

51. Popper, K. Letter. New Sci. 1981, 87, 611.

52. Dennett, D.C.; Plantinga, A.; Plantinga, A.; Philosophe, E.U.; Plantinga, A. Science and Religion: Are They Compatible; Oxford University Press: New York, NY, USA, 2011.

53. Glaze, A.L.; Goldstein, M.J.; Dantzler, J. Evolution in the Southeastern USA: Factors influencing acceptance and rejection in pre-service science teachers. Inter. J. Sci. Math. Educ. 2015, 13, 1189-1209. [CrossRef]

54. Allgaier, J. Scientific experts and the controversy about teaching creation/evolution in the UK press. Sci. Educ. 2010, 19, 797-819. [CrossRef]

55. Williams, J.D. Creationist teaching in school science: A UK perspective. Evol. Educ. Outreach 2008, 1, 87. [CrossRef]

56. Deniz, H.; Donnelly, L.A.; Yilmaz, I. Exploring the factors related to acceptance of evolutionary theory among Turkish preservice biology teachers: Toward a more informative conceptual ecology for biological evolution. J. Res. Sci. Teach. 2008, 45, 420-443. [CrossRef]

57. Taşkın, Ö. Pre-service science teachers' acceptance of biological evolution in Turkey. J. Biol. Educ. 2013, 47, 200-207. [CrossRef]

58. Donnelly, L.A.; Kazempour, M.; Amirshokoohi, A. High school students' perceptions of evolution instruction: Acceptance and evolution learning experiences. Res. Sci. Educ. 2009, 39, 643-660. [CrossRef]

59. Heddy, B.C.; Nadelson, L.S. The variables related to public acceptance of evolution in the United States. Evol. Educ. Outreach 2013, 6, 1-14. [CrossRef] 
60. Lee, H.; Yoo, J.; Choi, K.; Kim, S.W.; Krajcik, J.; Herman, B.C.; Zeidler, D.L. Socioscientific issues as a vehicle for promoting character and values for global citizens. Inter. J. Sci. Educ. 2013, 35, 2079-2113. [CrossRef]

61. Zeidler, D.L. Socioscientific Issues as a Curriculum Emphasis: Theory, Research, and Practice. In Handbook of Research on Science Education; Lederman, N.G., Abell, S.K., Eds.; Routledge: Abingdon, Oxon, UK, 2014; pp. 697-726.

62. Shilhav, Y. The emergence of ultra-Orthodox neighborhoods in Israeli urban centers. In Local Communities and the Israeli Polity; Ben-Zadok, E., Ed.; State University of New York Press: Albany, NY, USA, 1993; pp. 157-187.

63. Shaked, H. Israel's official policy with regard to teaching evolution in public schools. Inter. J. Jew. Educ. Res. 2014, 7, 93-111.

Publisher's Note: MDPI stays neutral with regard to jurisdictional claims in published maps and institutional affiliations.

(C) 2020 by the authors. Licensee MDPI, Basel, Switzerland. This article is an open access article distributed under the terms and conditions of the Creative Commons Attribution (CC BY) license (http://creativecommons.org/licenses/by/4.0/). 